\title{
Female Involvement in the Miners' Strike 1984-1985: Trajectories of Activism
}

\author{
by Jean Spence and Carol Stephenson \\ University of Durham; University of Northumbria
} Sociological Research Online, Volume 12, Issue 1,
< http://umw.socresonline.org.uk/12/1/spence.htm/>
doi:10.5153/sro.1461

Received: 8 Sep 2005 Accepted: 23 Jan 2007 Published: 31 Jan 2007

\begin{abstract}
This paper is based on recent primary research interviews with women who were active in the 1984-1985 miners' strike. The paper claims that one depiction of women's engagement in the strike has been privileged above others: activist women were miners' wives who embarked on a linear passage from domesticity and political passivity into politicisation and then retreated from political engagement following the defeat. This depiction is based on a masculinist view which sees political action as organisationally based and which fails to recognise the importance of small scale and emotional political work which women did and continue to undertake within their communities. In reality many women were politically active and aware prior to the dispute though not necessarily in a traditional sense. Women's activism is characterised by continuity: those women who have maintained activism were likely to have been socially and/or politically active prior to the dispute.
\end{abstract}

\section{Keywords: Miners' Strike, Masculine Understandings of Female Activism}

\section{Introduction}

$1.1^{[1]} \mathrm{A}$ popular reading of women's participation in the 1984-5 Miners' Strike suggests that this was a singular moment of working class female activism. Media representations from the period, including photographs, newspaper reports and the women's own publications show them in collective kitchens, at community and cultural events, at rallies and on picket lines (e.g. The Times, June 18th 1984,2; Coventry Miners' Wives Support Group 1986). At one level the messages being communicated speak of the value of the traditional roles of support and sustenance associated with women and mining. At another they focus upon the importance of a politicised and self directing female organisation and activism. The message, which is also reflected in other literature associated with the strike is that the women's struggle was exemplified by their adopting both roles and that it was this combination which ensured that their campaign was particularly powerful (ed. Samuel et al, 1986; ed. Seddon, 1986). The miners' strike apparently drew upon and reaffirmed traditional female roles whilst at the same time creating the circumstances whereby these roles became articulated with the class struggle by drawing women into the arena of trade union political action. The process of engagement with the strike is often understood to have radicalised the women, precipitating their engagement with class, labour and gender issues in a manner which extended the reach of, but at the same time was consonant with traditional industrial politics (ed. Beynon, 1985; Rowbotham and McCrindle, 1986)

1.2 It is possible to deduce from these characterisations of women in the strike a simple narrative of linear progression from individual/family concerns, to collective action, to political engagement (Coulter et al, 1984). The idea of the strike as a journey towards political consciousness which at one and the same time both reaffirmed and transformed class and gender identities, retains its influence in the public imagination and is apparent in recent historical characterisations, exemplified by the BBC1 Drama, Faith, (first shown in February 2005). However, a number of commentators have suggested that this model is too simple. For example, in 1991 Waddington et al. argued that the impact of the strike upon the political awareness of all those involved had been exaggerated (p148) both in terms of socialist and feminist understanding. Echoing some of the findings of this study, Shaw's research (1993) describes for some a movement away from political activity back into private concerns, expressed as a desire to 'return to normal' and to pick up the pieces of disrupted lives in the years immediately following the strike. Strangleman's work meanwhile (2001), demonstrates that by the end of the century, the strong community networks which were so important to the political solidarity of the strike are now more likely to be mobilised as welfare support 
rather than as political action.

1.3 This evidence and the findings of subsequent investigations (eg. Waddington 2001, 2003; Allen 2000, 2001) indicates that over the long-term the development of political understanding and the patterns of activism associated with the strike and with mining life is not simple. Although there were undoubtedly some women who did move in a straight line from private concerns to community organisation to political action and consciousness, there were many who did not.

1.4 This article explores the patterns of activism of a number of women who were active in the strike. Our intention is not to focus on all women who were involved in the strike but on those that do not have a place in the popular mythology of the dispute, or in the dominant discourse of women's activism. We argue that it is necessary to move beyond the unitary view of 'mining women' in order to understand the nature of subsequent community and political engagement amongst some of the women concerned. In addressing the differences between the women who participated in the dispute, it becomes apparent that the linear model of transformation is too simple. It depends upon stereotyped and romanticised views of gender roles and class consciousness within mining families and communities. As a consequence, the work women undertook in support of the strike, particularly their emotional work, is unrecognised and a masculine view of political action is not challenged.

\section{The Research}

2.1 The empirical evidence presented here was gathered in the north east of England, mostly in County Durham. It derives from a series of on-going studies which began during the winter of 1984-5 when Shaw made a video recording of women activists in which they discussed their understanding of the relevance of the strike and their feelings about their involvement.

2.2 Between 1985 and1987, 32 women participated in semi-structured, group and individual interviews in which they reflected upon the meaning of the strike and considered its impact on their lives (Shaw, 1993). Nine of these women were re-interviewed between 2002 and 2004 (Shaw and Mundy, 2005) with the purpose of assessing their longer term understanding of its consequences and their responses to the contemporary, post-mining environment in which they now lived.

2.3 In the context of a discussion about the long term effects of the strike and the transmission of values to the next generation, one of the interviewees offered to organise a research meeting with a Savings Group in an ex-mining village. The Savings Group, which included three women who had participated in the strike and three who were too young to remember mining or the strike in their village discussed issues relating to community, identity, and the relevance to their lives of values associated with mining.

2.4 Most recently, at a conference to commemorate the 20th anniversary of the strike a national forum, comprising 18 women strike activists was held. With their permission, the two hour, self-directed discussion covering their strike experiences and contemporary issues, was recorded for the purposes of the research. The names of those who have participated in this research are anonomysed here.

2.5 This work is a continuation of the personal/political engagement of members of the research group with the strike, with Women Against Pit Closures (WAPC), and with political activism associated with mining (Shaw, 1993; Spence, 1998; Suddick, 2005). In this sense it is not disinterested; the approach is akin to that outlined by Fox (2003) who argues for collaborative and transgressive research, and the researchers have been keen to include participants in the gathering and interpretation of the evidence.

2.6 The ethics of this research process involve enhancing the reflexivity of activists as well as researchers (Schön, 1983). For example one of the women who played a central role in women's support groups during the strike has participated in research group discussions, helped to analyse the data and facilitated contacts with activist women. In return members of the research team have contributed toward the creation of a Women Against Pit Closures web site which is part of a larger project to develop an archive of women's strike material. This was initiated as a result of the women's forum discussion. There has been a wider contribution from the research team towards the development of community and cultural projects associated with mining 'heritage' and identity.

2.7 The work of the research group has thus spilled out beyond pure research and this has necessitated some boundary management. Questions of objectivity and the 'truthful' representation of the meaning of the data have been an important aspect of research discussions. Ultimately, the data is presented as a means of 'grounding' an analysis whose questions derive from personal and collective experience and whose insights have emerged from processing those experiences through debate. These discussions have revealed how fully the personal and the political are intertwined in our own intellectual journeys and life narratives and this has therefore been a starting point for understanding the trajectories of the women who 
participated in the strike.

\section{Romanticism and Stereotypes}

3.1 The popular representations of women's role during the strike depend to a large extent upon stereotypes and generalisations which are hard to sustain in the face of the empirical evidence. At its root, the linear model of activism depends upon a set of assumptions which presumed firstly that all those involved were 'miners' wives' and secondly, that such women were characterised by domestic passivity and an absence of political consciousness prior to the dispute. It is certainly the case that the women's support groups which emerged in mining areas were forged in the first instance mainly by women who were directly connected with mining, though they were not necessarily 'miners' wives'. However, other women allied themselves with the struggle from the outset. For instance:

What I concentrated on, and not being a miner's wife, or anybody's wife indeed, was I concentrated on collecting, and I did, and I was part of Stoke Miners' Support Group and we met every week and we were involved with the miners' wives but we had separate activities. (Liz in Women's Forum, 2004)

or as Doreen told us:

As I was not married to a miner,[ but I can clarify] why I got involved. I had a well educated background but was kicking against middle class values though in retrospect I think I was just confused. My paternal grandfather and relatives were miners and my parents were both professional educators.... (written account of her involvement, 2003)

3.2 Even when the women involved were directly related to miners, the stereotypes associated with this circumstance cannot be sustained. Undoubtedly, these were rooted in an historical understanding of the real structural conditions of traditional mining villages and they certainly lent a certain 'authenticity' to the women's struggle (Spence, 1998) but by 1984, there was no longer a unitary way of life for women in mining localities. For instance, wives were more likely to be working part-time or full-time and their lives were no longer consigned to total domesticity. It is telling that in one of the support groups:

the ladies that actually did the kitchen was miners' mam's, grandmas, and they were the cooks....Alice is sitting over there; it was her mother in law that set the kitchen up and I'm talking about ladies, I hate to mention ages, but we are talking about ladies in their sixties, setting the kitchens up...(Vera, Women's Forum discussion, 2004)

3.3 In addition, mining families no longer lived in homogeneous communities. Mines had closed a cross Britain and mining employment had declined from 600,000 in 1931 to 269,000 by 1981 (Townsend and Hudson, 2005). The pattern of closure in the north east had begun in the west of the region and this meant that miners frequently had to travel distances in excess of ten miles to work. Women in these circumstances could draw on no local 'community' of mining women:

I didn't live in a mining community; a former mining community I did, but actually our men travelled to Sunderland, because I live in Beamish, which was a good trek. And I felt I was there on my own, and you didn't know that there was anything else existed in the coal field at all...My husband always knew he could go to Wearmouth, but there was never any talk about what women did, and you had to find that out for yourself...(Maggie, Women's Forum discussion, 2004)

We didn't get the support in this village during the miners' strike. It was just the miners' wives that stuck together. Other people said 'You've got a job. Get back to it!' And we were cut off from Durham and from the Stanley side - we were stuck in the top......ours was the first pit to go in 1949. [after that] The miners were like gypsies, travelling miners you know, right round, they drifted, Lanchester...Annfield Plain, Marley Hill colliery and then when they all closed, they went to the coast pits. (Dot, Interview, 2003)

3.4 Meanwhile, female action associated with the strike did not always emerge either from a traditional domestic role, or from a blank political slate. Some women were influenced by a family tradition of female activism associated both with mining and with the labour movement in general:

I remember my mam talking about the 1926 Black Marias being at the top and bottom of these streets during the miners' strike and you know, to get the miners to work...and my mam and dad hadn't spoken to them [strike breakers] from 1926...My mam she can vividly remember the street being blocked off to get them to work...(Katherine, interview, 2002) 
My mother...was the most active woman you ever knew in your life...She lived in Stockton but the Campaign Group in Middlesbrough put a plaque up to her in the Trade Union place.....and they have named a room after her...It says 'May $X X X$, Socialist, Internationalist, and thorn in the side of XXXAuthority' because that's what she always was....you name it, my mother was in it. But she was also a lay delegate from the Party to the Borough Council and to the county council...she was on every march... and she was still governor of a school when she was 90. (Jill, Interview, 2003)

3.5 Not least, some of the women themselves were already community or political activists at the outbreak of the strike:

Lillian was a Tyne and Wear county councillor before the strike...(Vera, interview, 2001)

We had a very good mentor in Lillian who from the start set us up as Chair, Vice-Chair, Treasurer. The Treasurer's position was done by the vicar's wife because we thought she would be the most honest. (Vera, Women's Forum, 2004).

3.6 Reference to the range of differences amongst the women who were involved, and to the wider context of their lives, thus reveals a range of narratives in which personal, community and political concerns can be seen to be inextricably interwoven within the trajectory of strike activism.

3.7 Nevertheless, there is a degree to which during the strike and in its aftermath, the women themselves attempted to act out and eventually to collude with stereotyped representations (Spence, 1998). In the context of defeat, it is perhaps inevitable that those who experienced the sacrifices of the struggle should seek to compensate for the bitterness of the defeat by focusing upon the positive, heroic and humorous aspects of that year:

This miner is getting a sack of potatoes to put in the garden. So he set them in the garden. One day, the wife had no tayties for dinner. So she went and dug them up. And she made it all nice, and he kept saying, 'These tayties are a long time coming up aren't they?' Isn't it funny that when you look back you think it was good? The funny times and things that happened. I mean really there were some horrendous times. (Dot, interview, 2002)

3.8 This tendency is reinforced by the characterisation of the miners' strike by the international labour movement as a heroic class struggle, exemplifying the socialist ideals of unity, political consciousness, selflessness and stoic determination to succeed against overwhelming odds. Yet as one of the women in the research recognised, it is important to demystify this if the lessons of the strike are to be of real value to others:

Unless we cut through the mythology and say how it was, then we'll never be able to see where we could do things better another time. Maybe on a different issue altogether, maybe supporting some other group of workers or whatever it was, but we don't - if we romanticise and well, tell ourselves lies if you like, about what went on, then we'll never be able to help anybody else. And that has been my concern, that we haven't yet broken through the mythology of the strike, which made out that everybody had become totally politicised. Some people did, there was a few who did, but there was an awful lot more who didn't get into the strike as anything like a collective effort at all. They collected the parcel, they went home, they shut the door on Sue. They shut the door on Sue and they weren't interested. They said no, they didn't want anything to do with it. (Jill, Women's Forum, 2004)

3.9 A complex combination of ambiguity and tension within labour movement and feminist politics relating to the strike, and a sophisticated understanding of 'audience', including the necessity of providing a unified and simplified message to the media, meant that it became politically expedient for the women to use traditional female roles in mining communities as a reference point for representing the terms of their action. Within this, the descriptive label 'miners' wives,' which of course did refer to a significant group of activists who were directly affected by the strike, became a convenient shorthand which encapsulated a further set of meanings about class location and comradeship with men in the women's campaign. That label has been creatively adopted by one group outside of the north east which continues to campaign around coal:

The group was actually formed in ' 85 when the strike ended ........so we decided to form the group as the 'North Staffs Miners' Wives' (Nicola, Women's Forum, 2004).

I remember us having a debate about whether we were going to call it the North Staff Women's Action Group or the North Staffs Miners' Wives Action group...we wanted a separate identity and it wasn't - Miners' Wives - a label that defines Brenda's relationship to 
her husband, it defined a relationship to a struggle, a class struggle around mining, and that was the difference and that is why we retained the name and went for the name Miners' Wives Action Group, even though on occasions people would say 'you are not a miner's wife'. I am not anybody's wife, but the Miners' wives had become the symbol of a struggle (Liz,

Women's Forum, 2004)

3.10 Despite this creativity, such labels remain open to interpretation as descriptive categories which carry a baggage of stereotyped and romantic meanings. Thus the long term significance of the participation both of miners' wives who were already politically informed and active, and of those women who were not miners' wives can be obscured. In the discussion which follows, we concentrate mainly upon the activism of women who do not fit the stereotypes and whose participation in the strike was integral to a longer term and continuous commitment to social and political organisation and action in coalfield areas.

\section{The personal and the political: emotional work}

4.1 Whatever their background and circumstances, many of the women who became active during the strike were motivated by immediate personal concerns. The loss of the mining wage and the inflexibility of strike benefit rules imposed by the Conservative Government (Witham, 1986; Warwick and Littlejohn, 1992) created an urgent need to provide support to single miners and to families thrown into destitution:

I got involved in it because my sister had died in pretty tragic circumstances and her husband was being treated as a single miner despite the fact that he had two kids. That was the start. I had to find out why that was. And all he was entitled to was milk tokens for the baby. So they were living on my mother's disability [benefits]... (Jean, interview, 2002)

4.2 In the process of participation in a strike which was emblematic of a much wider labour movement struggle against the encroachments of Thatcherite neo-liberalism, politicisation was almost inevitable:

I think we all became politicised - involved in politics even though probably before the strike I was an armchair politician. I used to argue with the television, but after the strike became very, very political. (Vera, Women's Forum, 2004)

If anybody asked me before if we'd be standing on the picket line like that, I would have said they would be lying, you know (Freda, Women's Forum, 2004)

4.3 However, such politicisation does not necessarily describe a linear movement, from the personal to the political. Rather, the women experienced a contextual shift into a public realm of political action which was hitherto unfamiliar. There is no evidence in our data that personal concerns were jettisoned in this process or even that, for everyone, they became politically understood.

4.4 The practical, personal responses of women were consonant with traditional female domestic responsibilities and perhaps inevitably, they thereby came to take major responsibility for the interpersonal and emotional work of the strike:

The men came over... and Vera says, ' How are the couples and single lads getting on?' He says, 'Whey that's up to you to find out! You're the women! Get on with it!' ....A couple what we had known very well, we found them huddled on the settee. She'd had a stroke. She was paralysed down this side, and suffered with fits and they were snuggled together lying on the settee. We took them some coal, what we could get, and bits of food, and you'd think they'd won the lottery, they were that grateful! And it was unbelievable. And I very often sit and cry now and think about them (Freda, Women's Forum 2004).

4.5 To some degree this reinforced the traditional gendered division of labour in the mining context but because it was undertaken in the public sphere and in support of a political struggle it also challenged the duality between emotional and political work. The women's contribution highlighted and legitimated the subjective and interpersonal aspects of political struggle. This could just as legitimately be framed as a personalisation of the political rather than a politicisation of the personal. The emotional bonds which existed between the women was crucial in sustaining their involvement in the dispute (Roth, 2005) and emotional support for those in crisis became a central aspect of the women's work.

4.6 Empathy, friendship, relationships became integral features of the miners' strike not only, but primarily through the women:

Friendship. Friendship. We looked after each other. (Dot interview, 2003)

If you are the sort of person who empathises with people you go through a million deaths you 
know. You do really because the cruelty that was going on through that strike, you know the rules and regulations that were applied to people, people who had no money and who were in desperate straits...(Jill, interview, 2003)

4.7 In some ways the everyday interpersonal and emotional work of the women which maintained morale and energy in the local context was hidden behind the readily available imagery of the organisation of kitchens, the involvement in picketing and the banners and rallies which precipitated women onto the public stage. Organisation remained privileged over small kindnesses, public speaking over quiet sympathy in leftist and popular media images of the strike. It is this dominant and ultimately traditionally masculine view of what counts as political activism which remains the over-riding image of the transformation of activism for women during the strike. The small scale, local and emotional labour in which women engaged, though vital, is once again neglected both in the popular press and within the left wing politics (Rowbotham et al 1979). Whilst these images are accurate, they foreclose the possibility of developing a fully feminised view of political activism during the strike.

4.8 Despite the hardship, this was a year that they would not have missed despite its difficulties. Their activism encouraged solidarity, it carried a powerful emotional charge associated with politics and in this it affirmed their personal and political identities, cementing their commitment to their local communities. The experience of the strike was therefore a pivotal moment in their lives. But its impact upon their personal futures and upon future political or community activism differed in relation to their previous circumstances and the manner in which they aligned themselves to the women's campaign.

\section{The return to locality}

5.1 There were many women who were directly affected by the strike, who became 'community activists' during its course insofar as they took their concerns into the collective and public arena. Yet some of these women refused all engagement with wider political organisation or with campaigning in the traditional sense during the dispute and in the longer term. There were others who experienced political activism as an exceptional moment. The activism of such women has been defined as 'accidental' (Hyatt, 1993), stimulated by circumstances, but fixed within time and place within individual biographies. It is the trajectories of these women which informed one view that after the strike women withdrew from political activism, however theirs is only one story.

5.2 Katherine, in an individual interview in 2002, spoke about her friends:

May was absolutely brilliant. She organised the kitchen and that...but that was as much as May wanted to be involved...I don't think May ever came to Durham, though people could have come to the bigger group if they had wanted to. She would come here to my house.....and an odd time we would go down to May's... but for people like May that was all she wanted to be involved with. And for May and others, when it ended, it ended. That was it, they went back to work....and that was it....Even Louise next door...we lived in each other's pockets - but when it was over, it was over and people just went back to what they normally did.

5.3 For women such as May and Louise, activity during the strike was constrained by the local and the familiar. They used their pre-existing skills in relation to their traditional domestic role and identity as women in a mining context which linked household and family with the idea of 'community' and neighbourhood. They did not venture outside this role and as a consequence there was little disruption to their pre-strike gender position or perspective. Their activism was continuous with this perspective but temporarily broadened to the public sphere.

5.4 Even when women did participate in organisation and action which took them beyond their traditional roles, they did not necessarily carry the political awareness and skill which had begun to emerge from this into the immediate post-strike period. It is apparent that after the defeat, 'Some women just wanted their lives back' (The Independent, 16th February 1995, p.29). Shaw's analysis demonstrates the extent to which the collapse of the mechanisms which during the strike supported their involvement, such as child care and travel expenses, contributed to the demise of activism as 'shared problems became once again, personal troubles' (Shaw, 1993 p175). Retreat was also provoked by gender expectations (Allen, 2001). Jill referred to the continuing power of men which she implicitly linked to the dominance of personal-family concerns over political ideas:

During the strike, the women had blossomed and started coming together and making decisions....but the men didn't want that; I mean most men. I'm not saying all men, but most men wanted to get back - as Dot Ryan would say to you, you know most people during the strike were just interested in their own families, they weren't really interested in the wider political issues at all... (Jill, Interview, 2003) 
5.5 Thus for different activist women and in different ways, the strike might be categorised and framed as a particular and aberrant moment in personal histories, to be bracketed out in the long term: their life trajectory following the dispute was continuous with their position before the strike. While this group of women have not been the focus of the research, anecdotal evidence suggests that these women returned to their neighbourhoods and used their experience of the strike the continued to inform their sense of responsibility towards others. For example, one woman known personally to the research team became a home help after the dispute and used this role to extend her networks which ultimately linked back to the continuing welfare responsibilities maintained by the NUM.

\section{The search for an organisational home}

6.1 The notion that all women activists returned to pre-strike locations feeds into the idea that after the strike, many women disappeared from activism. Rather our data suggests that activist women turned their attention to bringing issues which had emerged during the strike to organisations and movements which had originally stimulated their participation. Their involvement in the strike raised particular questions about the nature of the Labour Party, the Peace Movement and feminist campaigns. Some women embarked, not always successfully, on a search for a new political 'home'. The important point to note is that they did this as individuals: it was the support groups which largely disappeared.

6.2 Initially it was hoped that the NUM would encourage the women's support groups to continue and for a short while the momentum of activism was maintained in the campaign to gain associate membership of the union. However, despite the efforts of Arthur Scargill, (NUM President) at the NUM conference in July 1985, union rules were invoked to refuse associate membership at a national level (The Times, 29th June 1985, p2 ). Given the narrowness of its industrial interests and constitution, it was perhaps inevitable that the NUM would adopt such a position.

6.3 There was theoretically more scope within Labour Party branches to reach out and to offer the women an organisational home where they might continue to build their community politics after the strike. However, the relationship between supporters of the miners and the Labour Party was fraught because of the antagonistic position adopted by the Party leadership in respect of the strike ballot. Although some women were able to pursue their individual political aspirations through the Labour Party, others would not contemplate joining and other established members left in disgust:

Chris left the Labour Party after the strike, having been a Councillor. She tore her card up 'cos she thought it was a bloody disgrace what Kinnock did. (Liz, Women's Forum, 2004)

6.4 The combination of class and gender politics rooted in loose collective organisation, incorporporated emotional and personal concerns in a community context which had been so effective during the strike proved problematic in the post-strike environment. The trade union and labour movements were unwilling to adapt in order to accommodate the personalised, gender based approach to community politics whilst the feminist movement was unable to integrate the class concerns of the women. For example, at a conference held in Durham after the dispute, to explore the possibility for further collaboration with Greenham Women (Suddick, 2004; Shaw, 1993) issues of class identity and the strategy of separatism pursued from the Greenham perspective created a barrier to further collective endeavour (Shaw and Mundy, 2005).

6.5 No pre-existing organisation was sufficiently sophisticated or flexible to embrace those women who sought to maintain the holistic approach to political action with its emotional and gendered connotations which had been able to embrace difference so powerfully and effectively in the support groups. Henceforward the women were constrained to pursue their own personal and political paths as individuals. Here the prestrike differences between the women became significant: the loss of the strike as an external focus meant that most support groups fractured along the lines of those differences.

\section{Political action, community and continuity}

7.1 Continuity characterises the experience of most of the women who remained active after the dispute. Those who had been in some way active either in their locality or in a political organisation were better able to continue, although that activism was affected by their experience of the strike. A few such as Vera became more formally involved in politics but most who continued were likely to have been in some way politically engaged prior to the strike. Their participation was part of a longer term history of activism which, outside direct campaigns for coal can be summarised into three main categories.

7.2 The first is that of a community-based activism which through the strike gained a particular political inflection. For example, prior to the strike Jean had been treasurer of the local community centre, had participated in the organisation of youth and leisure activities and had always linked sociability in her neighbourhood with ideas about social justice. As an employee of the Mechanics Union she was positioned 
at the outset of the strike to link her community and trade union politics. The strike facilitated her access to a wider network of activists and she quickly became a central organiser of WAPC. As a result of this, Jean's pre-existing expertise in building what Putnam (1999) describes as 'bonding social capital' was extended during the strike and has enabled her to build 'bridges' between the realities of her immediate social world and wider political issues on a global stage. Accessing and using 'bridging' social capital has become a central feature of Jean's activism since the strike, although her experience in this matter has not been straightforward and she frequently encounters obstacles in the institutional world which confers the capital vital to operating on a wider stage.

7.3 In the light of these obstacles, Jean has built mainly on her persona as a good neighbour and community organiser but with deeper political insight and motivation. For example, she facilitates the local savings group which is part of this research. The group, which encourages its members to save small amounts regularly, is organised informally by women aged between 23 and 60 . Its participants understand this as a practical and also a political and collective response to the problem of personal debt encouraged by loan companies which target working class women (Spence and Stephenson, 2004). What is particularly significant about this is the manner in which the group operates as an arena for informal education which affirms the values associated with mining community as exemplified in the political activism of the strike.

7.4 Whilst this type of politicised community activism does have an impact upon participants, there are problems with its reach and with its sustainability in the long term, because of its lack of a wider organisational framework. Nevertheless, Jean has a resilience which echoes the determination of the women in the strike. She constantly seeks to link her personal activism with wider movements. At the same time, despite problems with formal institutional access, she maintains a set of personal contacts with academics and political activists which through the internet, are extended to the international stage. Such informed voluntary community activism is a legacy of the strike and a resource which has never been acknowledged by social policy initiatives designed to foster neighbourhood regeneration.

7.5 The second category is generally associated with feminism and related peace movements. Some women, such as Liz connected via Women's Refuges and Doreen from the Peace Movement, were 'brought into' a class based dispute through feminism (Stead 1987; Knight et al, 1986). They would not necessarily describe themselves as 'working class'. For example, Doreen indicated that she is from a 'well educated', 'middle class' background. Her memory of the strike was of 'sisterhood':

...the like of which we have never experienced before and probably will never experience again...we had found something special in the joint struggle. Women came together, of all classes, beliefs and political view points and we worked together for a common goal. (Doreen, written account of her activism, 2003).

7.6 These women retained their feminist politics but gained an enhanced understanding of class based injustice which they took forward into their subsequent individual professional and political lives. Doreen, for example went on to train as a welfare rights adviser. At the same time, Katherine, without identifying herself as a feminist, had been profoundly influenced by the politics of women she worked alongside and those of female family members. She went on to development herself as a woman, studying a degree and developing a professional career in social care.

7.7 The third category emerged from previous Party political involvement. Women who had been members of the Labour Party prior to the dispute were generally able and willing to continue afterwards. This was the largest proportion of women in our sample who remained organisationally active after the strike (Suddick, 2005).

7.8 Continuing Party membership provided these women with an organisational platform through which local concerns could be aired and practical action taken. These women, like those involved in community activism, tend to be fiercely committed to local politics. They have fought hard on local issues such as open cast mining, for local resources particularly for the young, and for the rebuilding of community amenities to regenerate community spirit. They are identified as 'friends' who listen to and care about people and who can also exert influence through the formal political system:

I have been a Parish Councillor since $1986 \ldots . .$. it has kept me going because it is something to do for the village. My family think I am crackers. They say, 'Mother, everyone looks after themselves now' and I say, 'But it is wrong, you have to look after each other!' It is starting to work because local people who have just moved in around here send Christmas cards and that is a start. So you send them back, and you say, 'Hello, do you fancy a cup of coffee? '...l'll say, 'Don't worry about your feet. l've done nowt yet - come on in!' They won't come to you - you have to go to them. (Dot, Interview, 2003) 
7.9 Participation in the strike afforded this group of women enhanced status as activists which they use to continue their work effectively in the local context. Notably, they have not used the strike either as an opportunity to make a professional career in politics or to pursue political power:

I'm in the Labour Party and I am a Parish Councillor. I could have been a District Councillor but I mean I never put in for it because .....well I had a friend was a County Councillor and she found that it took her away from the people. (Ethel, interview, 2003)

7.10 This interweaving of personal and political concerns which predates the strike, was effectively mobilised in its support and continues afterwards. The strike affirmed and gave concrete expression to these women's beliefs, but it did not create them.

7.11 These categories within a continuing pattern of activism illustrate firstly the significance of commitment to an ideal or set of principles - whether to 'community' or to a political philosophy, in provoking the activism of some women during the strike. Those motivated in this manner have been most likely to remain active in the long term. Secondly, they imply that for most of these women, the strike did not rupture their life course and set them on an entirely different path. Indeed of the working class women involved in this research only two had gone on to study in higher education and only one subsequently developed a professional career. For the majority the strike enhanced their political awareness and presented them with opportunities which had previously seemed out of reach, but it did so in a context which was usually prefigured by pre-strike interests, identities and desires. Thirdly, they indicate the importance of the appeal of the miners' strike to concepts of justice which were larger than the immediate industrial case and in which home, community and work, private and public, personal and political were one.

7.12 The failure of the political organisations of the left and of feminism to adapt in order to embrace this meant that the creative energies of the women as a collective were marooned. Inevitably, in response, many women returned as individuals to pre-strike institutional locations, non-political as well as political in order to deal with the future.

\section{Conclusion}

8.1 The women who participated in our research are a small fraction of those who were publicly active in the north east of England during the strike. They were activists who made a special contribution to the dispute and who continue to be active within their communities. These women are accessible to the researchers, and ultimately to each other, because of their continuing involvement in public life. The account of their lives prior to, during and after the dispute differs from the linear stereotype of miners' wives moving from domestic political passivity into the public political arena. These women were not exclusively wives of miners, nor were they necessarily ensconced in a domestic sphere or one of political passivity at the outset of the dispute.

8.2 There has been a tendency within the labour movement to exaggerate the extent of the political involvement of women during the strike. This in turn has exaggerated the significance of the defeat in terms of the destruction of the values associated with mining life and has fed a pessimism in relation to the longterm possibilities for collectivism in ex-mining communities. It seems difficult to suggest a positive future for socialist and feminist politics if, after the strike, 'people just went back to what they normally did'. Yet such pessimism hinges partly on the romance of 'mining community', partly on the myth that women associated with mining previously existed only in a non-political domestic sphere, and that the closure of the mines inevitably meant the destruction of stable and supportive mining families and communities. As women activists were held to have 'disappeared' (apparently back into the home) so their political values seem to have been lost. This notion of these women disappearing into political inertia is based on a masculinist ideal which sees political action as overt, organised and typically existing within the confines of party or trade union. This stance fails to appreciate women's strong attachment, past and present, to emotional work and attention to the intimate needs of people in struggle in the context of community.

8.3 In reality the pattern of women's trajectories of activism is one of continuity. Those that had been inactive in a traditional sense prior to the dispute were more likely to retreat from overt political action. Of these women, those that had been active within their community remained active there but with a raised political consciousness: the political contribution of these women to their communities has been neglected as a consequence of masculine conceptions of political action. Those that had been active within political organisations largely were able to return to these with altered agendas for political action.

8.4 We would not take issue with an analysis which is based on material conditions, nor dispute the extent of economic decline in ex-mining localities. However our evidence points to a continuing commitment to ideals of justice and equality and to a low-level continuing activism of those women who were key organisers during the strike. Such women work persistently towards a reproduction of the broad values 
promoted within the women's support networks during the strike. This draws primarily upon the everyday world of family and neighbourhood with a keen commitment to the notion of community.

8.5 Support for their efforts and to encourage new generations to be involved in political action of this nature, requires that organisations and activists think beyond the dualisms of personal/political; private/public; individual/collective and home/work in order to more fully understand the impact of the strike. These dualisms help to model a particular level of understanding, but they also obstruct the view. The relationship between these arenas is much more interesting than their oppositional positions.

\section{Notes}

${ }^{1}$ The research team comprises: Mave Mundy, Monica Shaw and Carol Stephenson, (University of Northumbria), Jean Spence (University of Durham), Gemma Metcalfe (Postgraduate student, University of Newcastle) Anne Suddick (Women Against Pit Closures).

\section{References}

ALLEN, M. (2001), 'Women, "Community" and the British Miners' Strike of 1984-85' in (eds) S.

Rowbotham, and S. Linkogle, 'Women Resist Globalization: Mobilizing for Livelihood and Rights', London: Zed Books

ALLEN, M. (2000) Carrying on the Strike: The Politics of Women Against Pit Closures into 1990's Ph.D Thesis, University of Manchester.

BEYNON, H. (ed.) (1985), Digging Deeper: Issues in the Miners'Strike, London: Verso

COULTER, J., Miller, S. and Walker, M. (1984) State of Siege: Politics and Policing in the Coalfields, London: Canary Press.

FOX, N. (2003) 'Practice-based evidence: towards collaborative and transgressive research', Sociology, 37(1) pp, 81-102

HYATT, S. (1993) ' "By the bottle of the people", activists' campaigns and the challenges of community development' prepared for the Annual General Meeting Churches Community Work Alliance, West Yorkshire Network, 14th October.

KNIGHT, L. et al, Annie; Judy; Millington, M., and Smailes, V. (1986) 'Mines not Missiles: Links with the Peace Women' in ed. V. Seddon, (op.cit)

PUTNAM, R. (1999) Bowling Alone. New York: Simon and Schuster.

ROTH S (2005) 'Sisterhood and exclusionary solidarity organization' in Flam H. and King D. Emotions and Social Movements Oxon: Routledge.

ROWBOTHAM S., Segal L. and Wainwright H. (1979) Beyond the Fragments: Feminism and the Making of Socialism. London: Merlin Press.

ROWBOTHAM, S. and McCrindle, J. (1986) 'More than just a memory: some political implications of women's involvement in the Miners' Strike, 1984-88' in Feminist Review, 23, Summer, pp109-124.

SAMUEL, R., Bloomfield, B. and Boanas (eds.) (1986), The Enemy Within: Pit villages and the miners' strike of 1984-5, London: Routledge \& Kegan Paul.

SCHÖN, D., (1983) The Reflective Practitioner: How Professionals Think in Action, New York: Basic Books.

SEDDON, V. , ed. (1986) The Cutting Edge: Women and the Pit Strike. London, Lawrence and Wishart.

SHAW, M.P., (1993) Women in Protest and Beyond: Greenham Common and Mining Support Groups, PhD Thesis, University of Durham

SHAW, M. and Mundy M., ( 2005), 'Reflections of active women of the 1984-5 miners' strike: then and now', Capital and Class, Special Edition, The Miners'Strike 20 Years On, No 87, Autumn.

SPENCE, J., (1998) 'Women, wives and the campaign against pit closures in Co. Durham: Understanding 
the Vane Tempest Vigil' Feminist Review, 60 Autumn, pp33-60.

SPENCE, J. and Stephenson, C., (2004) 'The Office: Strategies for survival in ex-mining communities', Paper given at Conference 'The Miners' Strike 20 Years On, University of Northumbria, July, 2004.

STEAD, J., (1987) Never The Same Again : Women and the Miners'Strike, London, Women's Press.

STRANGLEMAN, T. (2001) 'Networks, Place and Identities in Post-Industrial Mining Communities', International Journal of Urban and Regional Research, 25 (2) June, 253-267.

SUDDICK, A. (2005), 'The Past we inherit, the future we build', Editorial in Capital and Class, Special Edition, The Miners' Strike 20 Years on, No. 87, Autumn.

THE INDEPENDENT, 16.2.95 'Lessons from the University of Life,' Lesley Gerard on the women whose education began in the soup kitchens of the miners' strike.'

THE TIMES, June 18th 1984, pg.2, Issue 661860 Col. A

THE TIMES, June 29th 1985:2, Col. A., Conference of Unity call by Scargill to miners' delegates' David Felton, Labour Correspondent.

THE TIMES, July 4th 1985, 10 Issue 62187,Col B, 'Rule changes Scargill will rue: David Hart on delusions that will speed NUM disintegration'

TOWNSEND, A., and Hudson, R., (2005), Coalfield regeneration 1981-2003 Employment and travel to Work, Centre for Regional and Development Studies, Durham University: Office of the Deputy Prime Minister.

WADDINGTON, D., Wykes, M. and Catcher, C. with Hebron, S. (1991) 'Split at the Seams? Community, Continuity and Change after the 1984-5 coal dispute, Milton Keynes: Open University Press.

WADDINGTON, D., (2001) Out of the ashes? The social impact of industrial contraction and regeneration on Britain's mining communities. Routledge.

WADDINGTON, D. (2003) Developing Coalfield Communities: Breathing new life into Warsop Vale, Bristol: The Policy Press

WARWICK D. and Littlejohn G. (1992) Coal, Capital and Culture: A Sociological Analysis of Mining Communities in west Yorkshire. London. Routledge and Kegan Paul.

WITHAM, J. (1986) Hearts and Minds: The Story of the Women of Nottinghamshire in the Miners' Strike, 1984-5. London: Canary Press 